\title{
Repeatability of Pre-Harvest Sprouting in Wheat
}

\author{
Eduardo Stefani Pagliosa1, Valeria Carpentieri-Pipolo1 ${ }^{*}$, Deoclécio Domingos Garbuglio², \\ Thiago Henrique Oro ${ }^{1}$, Karla Bianca de Almeida Lopes ${ }^{1}$, Claudemir Zucareli ${ }^{1}$ \\ ${ }^{1}$ State University of Londrina, Londrina, Brazil \\ ${ }^{2}$ Agricultural Research Institute of Paraná State-IAPAR, Londrina, Brazil \\ Email: *valeriacarpentieri@gmail.com
}

Received 23 March 2014; revised 22 April 2014; accepted 4 May 2014

Copyright (C) 2014 by authors and Scientific Research Publishing Inc.

This work is licensed under the Creative Commons Attribution International License (CC BY). http://creativecommons.org/licenses/by/4.0/

c) (i) Open Access

\section{Abstract}

This study aimed to detect genotypic differences in the resistance to sprouting of wheat grains, evaluate the effectiveness of different methods for inducing sprouting and identify, using repeatability estimates, the minimum number of spikes necessary for the adequate evaluation of the percentage of grain sprouting in the spike in order to assist in the selection of superior genotypes in breeding programs. Spikes from four wheat cultivars (Frontana, IPR Catuara, Quartzo and BRS 220) were evaluated using three methods for inducing grain sprouting in the spike (water immersion, rainfall simulation and germination chamber). To determine the most efficient method, repeatability coefficients were estimated through analysis of variance, principal components analysis and structural analysis based on correlation and covariance matrices. The induction of sprouting by immersion in water was the most effective method for indicating genotypic differences and may be used in breeding programs for this purpose. The repeatability method based on the components of covariance was more efficient. A minimum of 11 spikes is required to make a high-reliability estimate of the percentage of sprouted grains in the spike.

\section{Keywords}

Triticum aestivum, Rainfall Simulator, Repeatability

\section{Introduction}

The environmental conditions in the areas where wheat is growing in Brazil favor the occurrence of rainfall in the harvest period, which in most cultivars may cause a high loss in germination potential and industrial quality

*Corresponding author. 
due mainly to grain sprouting in the spike [1] [2]. The process of grain sprouting in the spike can also be influenced by the dormancy period of the cultivars [3].

The sprouting of wheat grains in the spike is induced by the absorption of water by the grains immediately after full maturation. This problem affects both rural and industrial producers because it reduces the potential yield of crops, negatively affecting hectoliter weight [4]. Sprouting reduces the market value of the grain because, depending on the level of sprouting, the grain becomes suitable only for animal consumption and cannot be used for flour production or any other application in the food industry [1].

The sprouting of wheat grain triggers a sequence of physiological processes, including the release of hormones and hydrolytic enzymes [5]. Considering a simplified version of the process, these authors reported that the hormonal activity of gibberellic acid in imbibed grains increases the synthesis of amylases, which hydrolyze the carbohydrate reserves of the grain and thereby reduce its quality. In this context, the selection of superior genotypes for the release of new cultivars, or the choice of superior parental lines for recombination, that demonstrate resistance to grain sprouting in the spike is a key factor in wheat breeding programs.

Similarly, the search for efficient methodologies that provide greater accuracy in the stratification of genotypes should be conducted because of their usefulness in the selection of cultivars [6]. The minimum number of spikes required for these methods should also be assessed, as this factor contributes to greater accuracy in the selection of superior genotypes and results in smaller expenditures of time and resources for the evaluation.

The central issue is to define not only the most appropriate parameters or methods but also those that best simulate the effect of preharvest sprouting in a homogenous manner and that provide a high level of repeatability; i.e., the results can be confirmed through the repetition of the experiment by the same researcher or by others when using different samples or genotypes from the ones originally tested.

Through the repeatability coefficient, one can determine the number of measurements required to predict the true value of each individual with a certain degree of probability $\left(\mathrm{R}^{2}\right)$, which represents the percentage of certainty of the prediction of the true value of the selected individuals based on " $n$ " measurements; this value is easily estimated and requires no controlled crossbreeding or study of progenies [7] [8]. In this sense, the repeatability coefficient is a highly suitable tool for determining the minimum number of spikes required to estimate, with a high degree of accuracy, the percentage of sprouted grains in the spike for the stratification of genotypes in wheat breeding programs.

Thus, this study aimed 1) to evaluate the effectiveness of different methods for inducing sprouting in spikes with genotypic differences in the resistance to sprouting and 2) to obtain repeatability estimates using different statistical methods to identify the minimum number of spikes necessary for the proper evaluation of the percentage of grain sprouting in the spike.

\section{Materials and Methods}

The spikes originated from an experiment arranged in a randomized block design with three replications at the Agronomic Institute of Paraná (Instituto Agronômico do Paraná-IAPAR), in Londrina, Paraná State (latitude $23^{\circ} 22^{\prime} \mathrm{S}$, longitude $51^{\circ} 10^{\prime} \mathrm{W}$ ) during the 2012 harvest season. The harvesting of the spikes was conducted in the preharvest period. Four wheat cultivars with different levels of sprouting in the spike were evaluated: Frontana (resistant), IPR Catuara (moderately resistant), Quartzo (moderately susceptible) and BRS 220 (susceptible). These cultivars were subjected to three methods of inducing grain sprouting in the spike, as described below.

a) Immersion in water: Three samples of 10 spikes per genotype were randomly collected and subjected to water immersion for 16 hours, followed by a six-hour period of exposure to air to remove the excess water contained between the spikelets in accordance with the method described by [9].

b) Rainfall simulator: Rainfall simulation was performed using a sprinkler (Model P5 with 3/8 nozzle) set at a height of $1.5 \mathrm{~m}$ from the spikes. Three replicates of 10 spikes per genotype were sampled, vertically allocated and fixed on a Styrofoam board. The simulation lasted six hours with a total of $630 \mathrm{~mm}$ of rain.

c) Germination chamber: Spikes were wrapped in a paper towel moistened with a volume of water corresponding to 2.5 times the weight of the paper substrate, then placed in a germination chamber. For each genotype, three samples of 10 spikes were taken.

Spikes from the three sprouting methods were wrapped in paper towels and placed in a germination chamber at $85 \% \pm 3 \%$ relative humidity and $27^{\circ} \mathrm{C} \pm 2{ }^{\circ} \mathrm{C}$ temperature and were subsequently removed for evaluation after six days. 
Each spike was individually assessed and identified before the induction of grain sprouting. Spike mass (SM), spike length (SL) and number of grains per spike (NGS) were evaluated without the destruction of the spikes. After the six-day period in the germination chamber, the spikes were dried and threshed manually, and the sprouted and unsprouted grains were counted for each individual spike. The percentage of sprouting (S \%) was calculated from the ratio between the number of sprouted and unsprouted grains.

\section{Statistical Analysis}

The results obtained for spike mass, spike length, numbers of grains per spike and percentage of sprouting were evaluated by the tests for normality and homogeneity of variances, indicating no need for data transformation. Analysis of variance was performed in a $3 \times 4$ factorial design, i.e., three methods of sprouting induction and four genotypes, with three replications. Comparisons between the means were performed using the Tukey’s test at a $5 \%$ probability level.

Because repeatability estimates vary depending on the nature of the variables, the properties of the genotypes and the conditions under which the plants are grown [10], repeatability coefficients were obtained using four different methods, as described by [11], for increased estimate reliability: analysis of variance (ANOVA); principal components, obtained from both covariance (PCCOV) and correlation (PCCOR) matrices; and structural analysis based on the theoretical eigenvalues of the correlation matrix (EVCOR). These methods were used to predict the minimum number of repetitions (spikes) needed for the proper evaluation of grain sprouting in the spike in the germination chamber and for the individual genotypes, as well as to determine the most efficient method for inducing sprouting.

For the ANOVA method, the number of repeated measurements was considered equal for all genotypes, using Model 2 as described by [11]: Yij $=\mu+\mathrm{Gi}+\mathrm{Aj}+\varepsilon \mathrm{ij}$, where Yij is the mean of the ith genotype in the jth cycle; $\mu$ is the overall mean of the experiment; $\mathrm{Gi}$ is the effect of the ith genotype under the influence of the permanent environment; Aj corresponds to the effect of the Ath cycle; and cij corresponds to the random error from the other causes of variation that are not included in the model.

The minimum number of measurements required to predict the true values of the evaluated traits, based on pre-established coefficients of determination $\left(R^{2}\right)(0.80,0.85,0.90$ and 0.95$)$, was calculated using the following expression: $\eta=\mathrm{R}^{2}(1-\mathrm{r}) /\left(1-\mathrm{R}^{2}\right) \mathrm{r}$, based on the mean value of $\eta$ cycles $(\eta=30)$ representing the 30 spikes used to estimate the repeatability. In the estimation of the r-values obtained by the different methodologies, $\mathrm{R}^{2}$ was calculated according to the following expression: $\mathrm{R}^{2}=\eta \mathrm{r} / 1+\mathrm{r}(\eta-1)$.

All statistical analyses were performed using the GENES software [12].

\section{Results and Discussion}

The analysis of variance (Table 1 ) was significant ( $<<0.05$ ) for the interaction between the induction of sprouting and genotypes only regarding the percentage of grain sprouting per spike (S \%). Significant differences were observed between the genotypes only for the spike mass (SM), spike length in cm (SL) and number of grains per spike (NGS) traits. These differences indicated that the wheat genotypes differed from each other, demonstrating that the selection of contrasting genotypes for the traits in question was efficient. The coefficients of variation ranged from $5.09 \%$ to $30.11 \%$, representing moderate to good accuracy for the data obtained in this study.

The Frontana wheat genotype showed superior performance, compared to the other genotypes, for SM, SL and NGS (Table 2). Franco et al. [13] had previously observed differences between genotypes in the number of grains per spike in the Palotina municipality, indicating the superiority of the CD 104, BRS 208 and Frontana cultivars. Similarly, these authors stated that the domestic wheat derived from Frontana likely transmitted the ability to produce a higher number of grains per spike to their offspring, which may have contributed to the increase in the grain yield of new cultivars.

Effective methods that contribute to the selection of cultivars with resistance to grain sprouting in spikes are of fundamental importance to breeding programs [6], as they enable the accurate identification of the genotypic responses regarding this characteristic. These methods serve as the basis for the selection of parental lines to build crossing blocks, as well as for the identification and selection of promising segregating populations. Thus, the method that induces sprouting most efficiently provides the greatest differentiation among genotypes.

Table 3 shows that the greatest stratification of wheat genotypes through a sprouting induction method was obtained by immersing the spikes in water. Genotype stratification was expected because Frontana, IPR Catuara, 
Table 1. Mean squares of analysis of variance (ANOVA) for Spike mass (SM), spike length (SL) and number of grains per spike (NGS) and the percentage of sprouting (S \%) for four wheat genotypes under three different forms of induction sprouting.

\begin{tabular}{cccccc}
\hline Source of Variation & D.F. & \multicolumn{3}{c}{ TRAITS } \\
\cline { 3 - 6 } & & SM & SL & NGS & S (\%) \\
\hline Inducing sprouting (I) & 2 & 0.047 & 0.150 & 4.210 & $982.55^{* *}$ \\
Genotypes (G) & 3 & $4.74^{* *}$ & $11.40^{* *}$ & $539.12^{* *}$ & $7146.54^{* *}$ \\
I $\times$ G & 6 & 0.018 & 0.290 & 4.230 & $340.77^{* *}$ \\
Error & 24 & 0.031 & 0.132 & 7.074 & 27.643 \\
Means & & 1.45 & 7.15 & 31.14 & 17.46 \\
C.V. (\%) & & 12.15 & 5.09 & 8.54 & 30.11 \\
\hline
\end{tabular}

D.F.: Degrees of freedom. ${ }^{* *}$ and ${ }^{*}: 1$ and $5 \%$ probability by F test, respectively.

Table 2. Comparison of means between four wheat genotypes to traits of Spike mass (SM), spike length (SL) and number of grains per spike (NGS).

\begin{tabular}{ccccc}
\hline \multirow{2}{*}{ TRAITS } & \multicolumn{3}{c}{ GENOTYPES } \\
\cline { 2 - 4 } & BRS 220 & QUARTZO & IPR CATUARA & FRONTANA \\
\hline SM (g) & $0.86 \mathrm{C}^{(1)}$ & $1.11 \mathrm{BC}$ & $1.32 \mathrm{~B}$ & $2.50 \mathrm{~A}$ \\
SL (cm) & $6.23 \mathrm{C}$ & $6.51 \mathrm{BC}$ & $7.13 \mathrm{~B}$ & $8.74 \mathrm{~A}$ \\
NGS & $27.54 \mathrm{~B}$ & $28.12 \mathrm{~B}$ & $26.21 \mathrm{~B}$ & $42.69 \mathrm{~A}$ \\
\hline
\end{tabular}

${ }^{(1)}$ : Means followed by the same letter (horizontal) indicate no significance at $5 \%$ of probability by Tukey test.

Table 3. Effect of three different forms of grains germination induction in the percentage of sprouting per spike trait (S \%) in four wheat genotypes.

\begin{tabular}{|c|c|c|c|c|}
\hline \multirow{3}{*}{ TRAITS } & \multicolumn{4}{|c|}{ GENOTYPES $^{(1)}$} \\
\hline & BRS 220 & QUARTZO & IPR CATUARA & FRONTANA \\
\hline & \multicolumn{4}{|c|}{$\mathrm{S} \%$} \\
\hline Immersion in water method & $85.02 \mathrm{aA}^{(1)}$ & $17.35 \mathrm{aB}$ & $6.71 \mathrm{aBC}$ & $1.25 \mathrm{aC}$ \\
\hline Rainfall simulator & $56.11 \mathrm{bA}$ & $1.14 \mathrm{bB}$ & $1.20 \mathrm{aB}$ & $0.20 \mathrm{aB}$ \\
\hline Germination chamber & $37.59 \mathrm{cA}$ & $1.61 \mathrm{bB}$ & $0.59 \mathrm{aB}$ & $0.81 \mathrm{aB}$ \\
\hline
\end{tabular}

${ }^{(1)}$ : Means followed by the same uppercase letter (horizontal) and by the same lowercase letter (horizontal) indicate no significance at $5 \%$ of probability by Tukey test.

Quartzo and BRS 220 were resistant, moderately resistant, moderately susceptible and susceptible for grain sprouting in the spike, respectively.

This differentiation of the genotypes was not observed for the rainfall simulator and germination chamber methods, which grouped the Frontana, IPR Catuara and Quartzo genotypes in the same category of spike sprouting response. [13] stated that rainfall simulation in a controlled environment was efficient in promoting sprouting only in susceptible cultivars; this result was confirmed by the present study, in which both the rainfall simulator and germination chamber methods were able to differentiate genotype BRS 220 (susceptible) from the other evaluated genotypes, showing percentages of grain sprouting per spike of $56.11 \%$ and $37.59 \%$, respectively. In contrast, Gavazza et al. [6], in an evaluation of the sprouting of wheat genotypes, observed that the rainfall simulation method was best suited for evaluating cultivars in terms of preharvest sprouting regardless of harvest time and evaluation site. 
After the immersion in water method was identified as the most suitable for the stratification of wheat parental lines, the repeatability analysis was conducted (Table 4). Repeatability coefficients (r) ranged between 0.90 and 0.97 , and the coefficient of determination $\left(\mathrm{R}^{2}\right)$ ranged between 99.64 and 99.90 . The high magnitudes of the repeatability coefficients and the coefficients of determination indicated that the mathematical model used was a satisfactory fit to the dataset [10]. According to [8], repeatability varies according to the nature of the trait evaluated, the genetic properties of the population and the environmental conditions under which the individuals are kept. Similarly, it is evident that the greatest accuracy of estimates was obtained by the method of principal components based on the covariance matrix (PCCOV), which had values of 0.97 and 99.90 for $r$ and $\mathrm{R}^{2}$, respectively. Other authors have also observed higher estimates using the PCCOV method in other species [10] [14]-[17].

High estimates of repeatability for a given trait indicate that it is feasible to predict the true value of the individual for that trait using a relatively small number of measurements, and the opposite is true when the repeatability is low [18]. [19] indicated that a rate of prediction for the true value of approximately $90 \%$, i.e., $\mathrm{R}^{2}=90 \%$, is considered quite satisfactory.

The method based on the ANOVA Model 2 gave less accurate estimates compared to the other methods. [10] in a comparison of different methods for the measurement of repeatability coefficient estimates in elephant grass, found that the estimates obtained by ANOVA Model 2 were always lower than those obtained using other methods. Similarly, [15] observed that lower estimates of the repeatability coefficients were obtained using the ANOVA method in soybean. According to Cruz et al. [8], the analysis of variance method may, in some cases, lead to the underestimation of the repeatability coefficients.

Cruz et al. [8] have stated that one of the main applications of repeatability analysis is to determine the number of observations necessary to estimate the true value of the analyzed variable with both the desired accuracy and the minimum cost and labor. Thus the PCCOV method, which requires one evaluation cycle to predict the true value of the wheat genotypes for the percentage of grain sprouting per spike if $R^{2}=95 \%$ (Table 4), is considered the best method in this study. For this method, increasing the number of measurements results only in a small additional increase in accuracy. The low number of evaluation cycles determined as necessary in this study can be attributed to the close fit of the covariance matrix used in the analysis with the dataset and its consequent high values of $r$, which reduced the necessary number of measurements [10].

However, the high accuracy obtained for all analysis methods (above 99\%) indicates that any of the methods evaluated in this study would be suitable for a highly accurate evaluation of repeatability. Thus, even in the comparatively lower accuracy ANOVA method, the minimum number of spikes required to determine the true value of the percentage of sprouting was 11 , for an accuracy of $99 \%$.

Table 4. Estimates of the repeatability coefficient (r), determination coefficients $\left(R^{2}\right)$ and number of measurements ( $\left.\eta\right)$ for percentage of sprouting per spike trait (S \%) of four wheat genotypes whose germination was induced by the water immersion method.

\begin{tabular}{|c|c|c|c|c|}
\hline & \multicolumn{4}{|c|}{ METHODS $^{(1)}$} \\
\hline & ANOVA-2 & PCCOV & PCCOR & EVCOR \\
\hline $\mathrm{r}$ & 0.90 & 0.97 & 0.93 & 0.93 \\
\hline \multirow[t]{2}{*}{$\mathrm{R}^{2}$} & 99.64 & 99.90 & 99.77 & 99.75 \\
\hline & \multicolumn{4}{|c|}{$\eta$} \\
\hline $\mathrm{R}^{2}$ & ANOVA-2 & PCCOV & PCCOR & EVCOR \\
\hline 0.80 & 1 & 1 & 1 & 1 \\
\hline 0.85 & 1 & 1 & 1 & 1 \\
\hline 0.90 & 1 & 1 & 1 & 1 \\
\hline 0.95 & 3 & 1 & 2 & 2 \\
\hline 0.99 & 11 & 3 & 7 & 8 \\
\hline
\end{tabular}

\footnotetext{
${ }^{(1)}$ : ANOVA: analysis of variance; PCCOV and PCCOR: principal components, obtained from both covariance and correlation matrices, respectively;
} EVCOR: structural analysis based on the theoretical eigenvalues of the correlation matrix. 
It is worth mentioning that a reduced number of evaluation cycles does not allow the researcher to obtain detailed information on the genotype $\mathrm{x}$ environment interaction or on the individual response of the genotype to environmental variations [10]. Therefore, further studies should be conducted to better understand the effect of genotypes, environmental conditions and the genotype $\times$ environment interaction for additional descriptors in order to estimate repeatability coefficients, coefficients of determination and the number of evaluations necessary to estimate the differences between samples [15].

\section{Conclusions}

The water immersion method for inducing sprouting in spikes was the most effective for identifying contrasting genotypes and can be used in breeding programs for this purpose.

The repeatability method based on the covariance components was the most efficient.

A minimum of 11 spikes is required to estimate the percentage of grain sprouting in the spike with $99 \%$ confidence.

\section{Acknowledgements}

The authors gratefully acknowledge CAPES (Coordenação de Aperfeiçoamento de Pessoal de Nível Superior) for their financial support.

\section{References}

[1] Cunha, G.R., Pires, J.L.F. and Pasinato, A. (2004) Introdução ao problema da germinação na pré-colheita em trigo no Brasil. In: Cunha, G.R. and Pires, J.L.F., Eds., Germinaçãopré-colheitaemtrigo. Embrapa, Passo Fundo, 11-20.

[2] Bassoi, M.C. (2004) Aspectos gerais da germinação pré-colheita e seu controle genético. In: Cunha, G.R. and Pires, J.L.F., Eds., Germinação pré-colheita em trigo, Embrapa, Passo Fundo, 21-136.

[3] Biddulph, T.B., Mares, D.J., Plummer, J.A. and Setter, T.L. (2005) Drought and High Temperature Increases Preharvest Sprouting Tolerance in a Genotype without Grain Dormancy. Euphytica, 143, 277-283. http://dx.doi.org/10.1007/s10681-005-7882-0

[4] Groos, C., Gay, G., Perretant, M.R., Gervais, L., Bernard, M., Dedryver, F. and Charmet, G. (2002) Study of the Relationship between Pre-Harvest Sprouting and Grain Color by Quantitative Trait Loci Analysis in a White $\times$ Red Grain Bread-Wheat Cross. Theoretical and Applied Genetics, 104, 39-47. http://dx.doi.org/10.1007/s001220200004

[5] Bassoi, M.C., Flinthan, J. and Riede, C.R. (2006) Analysis of Pre Harvest Sprouting in Three Brazilian Wheat Populations. Pesquisa Agropecuária Brasileira, 41, 583-590. http://dx.doi.org/10.1590/S0100-204X2006000400006

[6] Gavazza, M.I.A., Bassoi, M.C., Carvalho, T.C., Bespalhok Filho, J.C. and Panobianco, M. (2012) Methods for Assessment of Pre-Harvest Sprouting in Wheat Cultivars. Pesquisa Agropecuária Brasileira, 47, 928-933. http://dx.doi.org/10.1590/S0100-204X2012000700008

[7] Costa, J.G. (2003) Estimate of Repeatability of Some Traits of Production in Mango Tree. Ciência Rural, 33, $263-266$. http://dx.doi.org/10.1590/S0103-84782003000200013

[8] Cruz, C.D., Regazzi, A.J. and Carneiro, P.C.S. (2004) Modelos biométricos aplicados ao melhoramento genético. 3rd Edition, Universidade Federal de Viçosa, Viçosa, Vol. 1, 480p.

[9] Linhares, A.G. (1976) Avaliação de linhagens e variedades de trigo quanto ao grau de germinação na espiga. In: Reunião Anual Conjunta de Pesquisa de Trigo, EMBRAPA/CNPT, Ponta Grossa, Vol. 1, 83-93.

[10] Cavalcante, M., Lira, M.A., Santos, M.V.F., Pita, E.B.A.F., Ferreira, R.L.C. and Tabosa, J.N. (2012) Coefficient of Repeatability and Genetic Parameters in Elephant Grass. Pesquisa Agropecuária Brasileira, 47, 569-575. http://dx.doi.org/10.1590/S0100-204X2012000400013

[11] Cruz, C.D. and Regazzi, A.J. (2001) Modelos biométricos aplicados ao melhoramento genético. 2nd Edition, UFV, Viçosa, 390p.

[12] Cruz, C.D. (2006) Programa Genes: Biometria. Editora UFV, Viçosa, 382p.

[13] Franco, F.A., Pinto, R.J.B.,Scapim, C.A., Schuster, I., Predebon, C.T. and Marchioro, V.S. (2009) Sprouting Tolerance on Spikes in Wheat Cultivars Harvested in the Physiological Ripening. Ciência Rural, 39, 2396-2401. http://dx.doi.org/10.1590/S0103-84782009005000212

[14] Martuscello, J.A.,Jank, L., Fonseca, D.M., Cruz, C.D. and Cunha, D.N.F.V. (2007) Repetibilidade de caracteres agronômicos em Panicum maximum Jacq. Revista Brasileira de Zootecnia, 36, 1975-1981. http://dx.doi.org/10.1590/S1516-35982007000900005 
[15] Matsuo, E.,Sediyama, T., Cruz, C.D., Oliveira, R.C.T. (2012) Analysis of the Repeatability in Some Morphologic Descriptors to Soybean. Ciência Rural, 42, 189-196. http://dx.doi.org/10.1590/S0103-84782012000200001

[16] Lédo, F.J.S., Pereira, A.V., Souza Sobrinho, F., Auad, A.M., Jank, L. and Oliveira, J.S. (2008) Repeatability Estimates for Forage Characters in Panicum maximum. Ciência e Agrotecnologia, 32, 1299-1303. http://dx.doi.org/10.1590/S1413-70542008000400040

[17] Souza Sobrinho, F., Borges, V., Lédo, F.J. and Kopp, M.M. (2010) Agronomic Traits Repeatability and Number of Cuts Needed for Selecting Urochloa ruziziensis. Pesquisa Agropecuária Brasileira, 45, 579-584. http://dx.doi.org/10.1590/S0100-204X2010000600007

[18] Cargnelutti Filho, A., Castilhos, Z.M.S., Storck, L. and Savian, J.F. (2004) Repeatability Analysis of Forage Traits of Panicum Maximum Genotypes Evaluated under Natural and Attenuated Solar Radiation. Ciência Rural, 34, 723-729. http://dx.doi.org/10.1590/S0103-84782004000300011

[19] Botrel, M.A., Ferreira, R.P., Cruz, C.D., Pereira, A.V., Viana, M.C.M., Rocha, R. and Miranda, M. (2000) Estimates of Repeatability Coefficients for Dry Matter Yield in Alfalfa Cultivars under Different Environments. Revista Ceres, 47, 651-663.

\section{Abbreviations}

SM: spike mass;

SL: spike length;

NGS: number of grains per spike;

$\mathrm{S} \%$ : percentage of sprouting;

ANOVA: analysis of variance;

PCCOV: principal components obtained from covariance;

PCCOR: principal components obtained from correlation matrices;

EVCOR: structural analysis based on the theoretical eigenvalues of the correlation matrix. 